\title{
Effect of buttermilk and skimmed milk powder on the properties of low-fat yoghurt
}

\author{
Anna Garczewska-Murzyn ${ }^{1} \cdot$ Michał Smoczyński $^{1} \cdot$ Natalia Kotowska $^{1}$ • \\ Katarzyna Kiełczewska ${ }^{1}$ (D)
}

Revised: 27 July 2021 / Accepted: 30 July 2021/Published online: 12 August 2021

(C) The Author(s) 2021

\begin{abstract}
The aim of the study was to determine the potential of using buttermilk and skimmed milk powders as additives to standardize the dry matter content of milk in the production of low-fat yoghurt. A batch of yoghurt was produced using a starter culture of Lactobacillus delbruecki ssp. bulgaricus and Streptococcus thermophilus. The rates of milk acidification and $\mathrm{pH}$ levels were similar for both variants of yoghurt. After chilled storage (21 days), the yoghurt produced from milk supplemented with buttermilk powder was found to contain higher $(P \leq 0.05)$ levels of lactic acid $(1.179 \%)$ than that supplemented with skimmed milk $(1.154 \%)$. The use of buttermilk powder allowed reducing (not significantly, $P>0.05$ ) syneresis in the stored yoghurt. The milk fat in the buttermilk-supplemented yoghurt showed lower $(P \leq 0.05)$ phospholipids content and exhibited slightly higher phospholipids loss during storage than the yoghurt produced from milk with addition of milk powder. No differences were found between the profile of fatty acids between the yoghurts enriched with skimmed milk powder and those enriched with buttermilk powder. Buttermilk can be used as an additive to produce a novel yoghurt type with modified functional features.

Research Highlights The use of buttermilk powder did not affect fermentation process, however increased lactic acid content and water-holding capacity of yoghurt.
\end{abstract}

Katarzyna Kiełczewska

kaka@uwm.edu.pl

1 Department of Dairy Science and Quality Management, Faculty of Food Sciences, University of Warmia and Mazury in Olsztyn, Oczapowskiego Str. 7, 10-719, Olsztyn, Poland
The yoghurts with added buttermilk contained less phospholipids when compared with yoghurts supplemented with milk powder.

Buttermilk powder can be incorporated as an ingredient in production of novel yoghurt type with improved functional features.

Keywords Yoghurt - Buttermilk powder · Phospholipids . Acidity $\cdot$ Syneresis
Abbreviations
MFGM Milk fat globule membrane
BMP Buttermilk powder
SMP Skimmed milk powder
MBMP Milk with buttermilk powder
MSMP Milk with skimmed milk powder
YBMP Yoghurt made from milk with buttermilk powder
YSMP Yoghurt made from milk with skimmed milk powder

\section{Introduction}

Both milk and dairy products are food items of high nutritional and dietary value due to their biologically active ingredients (Korhonen 2009). Particularly noteworthy are powdered milk products-powdered milk, powdered buttermilk, powdered whey, concentrates of all milk proteins and whey protein concentrate-which can serve as interesting food additives due to their useful properties and nutritional values, mainly due to their proteins (Silva and O'Mahony 2017). Buttermilk as a powdered product can potentially boost the nutritional and health-promoting properties of foodstuffs, as well as modify their structure and consistency. Buttermilk contains all of the water- 
soluble milk constituents, including milk proteins, lactose and minerals, as well as large quantities of milk fat globule membranes (MFGM) (Smoczyński et al. 2012). During the churning process, fragments of the membranes are released into the milk plasma, resulting in higher levels of polar lipids in the dry matter of buttermilk (Dewettinck et al. 2008; Vanderghem et al. 2010) and in the milk fat (Contarini and Povolo 2013; Rombaut and Dewettinck 2006) when compared with whole milk, cream or butter. It can serve as valuable raw material for extracting MFGM components, whose functional and health-promoting properties have been noted by many researchers. The components of the membrane, including polar lipids and MFGM proteins, support the healthy functioning of the body, and may thus be added to food products to enrich their composition and improve their nutritional and biological values (Anto et al. 2020; Conway et al. 2014; Contarini and Povolo 2013; Corredig and Dalgleish 1997; Dewettinck et al. 2008; Fontecha et al. 2020; Spitsberg 2005; Vanderghem et al. 2010). Given their functional features, i.e. their structure-forming, emulsifying and water-binding properties, buttermilk and MFGMs can be utilized in cheesemaking, yoghurt-production, and other technological processes (Dewettinck et al. 2008; Vanderghem et al. 2010).

Yoghurt is a dairy product obtained through fermentation with starter cultures containing Lactococcus delbruecki ssp. bulgaricus and Streptococcus thermophilus bacteria (Horiuchi and Sasaki 2012). It belongs to the group of concentrated fermented milks. The concentration of yoghurt dry matter components is an important determinant of the texture, composition, and rheology of the final product. One of the methods used to increase the concentration of milk dry matter components is to add powdered milk or powdered milk proteins prior to the acidification (Jørgensen et al. 2019). Fortification of the dry matter content through the addition of sweet buttermilk prevents syneresis and improves the structure and texture of low-fat yoghurt (Trachoo and Mistry 1998). Milk fat, both in terms of its dispersion and fatty acid composition, plays an important role in developing the taste and consistency of yoghurt. For this reason, yoghurt substitutes that could be used in low-fat products are sought these days. Through the use of buttermilk, sensory attributes of low-fat yoghurts can be modified to resemble those of full-fat yoghurt (Zhao et al. 2018).

Due to the beneficial effects of buttermilk in fermented milk technology, the aim of the present study was to determine the potential of using buttermilk and skimmed milk powders as additives in the production of low-fat yoghurt.

\section{Materials and methods}

\section{Research material}

The research material encompassed bulk milk obtained during winter from farms in Warmia-Mazury Voivodeship, as well as sweet buttermilk powder and skimmed milk powder produced in an industrial facility.

\section{Study design}

Raw milk was centrifuged at $45{ }^{\circ} \mathrm{C}$ in a skimming separator (Gea Westfalia Separator System GmbH, Oelde, Germany) to skim the milk and standardize its fat content. The dry matter content of milk was standardized to $13 \%$ using buttermilk powder (BMP) and skimmed milk powder (SMP). Then, the cream with $30 \%$ content of fat was added to the milk with buttermilk powder and milk with skimmed milk powder to standardize their fat content to $1.5 \%$. The prepared milk samples were subjected to a two-step homogenization process at a temperature of $65^{\circ} \mathrm{C}$ and pressures of $\mathrm{p}_{1}=15 \mathrm{MPa}, \mathrm{p}_{2}=3 \mathrm{MPa}$ using a PandaPlus 2000 homogenizer (Gea Niro Soavi, Italy), as well as to a pasteurization process at $95{ }^{\circ} \mathrm{C}$ for $60 \mathrm{~s}$ using a Thermomix TM 31 (Vorwerk, Wuppertal, Germany). After the milk was chilled to $45{ }^{\circ} \mathrm{C}$, a freeze-dried YC-X11 Yo-flex starter culture (Chr. Hansen, Hoersholm, Denmark) containing Lactobacillus delbruecki ssp. bulgaricus and Streptococcus thermophilus species was added as an inoculum. The samples were then thoroughly mixed, placed into plastic cups and incubated at $45^{\circ} \mathrm{C}$ until $\mathrm{pH}$ of 4.6-4.7 was reached. After attaining target $\mathrm{pH}$, the yoghurt was chilled to $4{ }^{\circ} \mathrm{C}$ and stored for 21 days. The tested samples included the milk with buttermilk powder (MBMP) and the milk with skimmed milk powder (MSMP) used for standardization, as well yoghurts produced from these sources: yoghurt made from milk with buttermilk powder (YBMP) and yoghurt made from milk with skimmed milk powder (YSMP), that were chill-stored for 1 day, 7 days and 21 days.

\section{Chemical composition}

The content of total solids was determined according to AOAC guidelines (AOAC International, 2007; method 990.20; 33.2.44). Fat content was determined with the Gerber method according to standard IDF 238 (ISO 19662, 2018). 


\section{Acidity}

The $\mathrm{pH}$ value was measured using a Testo $205 \mathrm{pH}$-meter (Testo, Titisee-Neustadt, Germany). Milk $(100 \mathrm{~mL})$ was titrated with $0.25 \mathrm{M} \mathrm{NaOH}$ using phenolphthalein as the indicator. The results were expressed as Soxhlet-Henkel degrees $\left({ }^{\circ} \mathrm{SH}\right)$. Lactic acid content were determined according to AOAC guidelines (AOAC International, 2007; method 947.05; 33.2.06).

\section{Syneresis}

Syneresis was measured by centrifuge testing (Amatayakul et al. 2006). The yoghurt sample was stirred 20 times in the clockwise and counterclockwise direction with a thin spatula. Ca. $20 \mathrm{~g}$ of yoghurt were transferred into polypropylene centrifuge tubes and left at $4{ }^{\circ} \mathrm{C}$ for $2 \mathrm{~h}$ to stabilize. Afterward, the samples were spun in a Heraeus Megafuge 16 (Thermo Fisher, Waltham, USA) at $3000 \mathrm{rpm}$ and $10{ }^{\circ} \mathrm{C}$ for $15 \mathrm{~min}$. After centrifugation, the separated whey was weighed. The syneresis was expressed as the percentage of the separated whey relative to the weight of the centrifuged sample.

\section{Extraction of the lipid fraction}

Fat was extracted from the yoghurt using the method described by Hara and Radin (1978). A 3:2 mixture of hexane and isopropanol was used for fat extraction. The samples were measured out into ground-glass conical flasks, after which $18 \mathrm{~mL}$ of a solvent mixture was added per $1 \mathrm{~g}$ of the test material. The samples were then vigorously stirred for $60 \mathrm{~s}$. An aqueous solution of sodium sulphate $\left(1 \mathrm{~g}\right.$ of salt dissolved in $15 \mathrm{~cm}^{3}$ of water) was mixed at a 12:1 ratio. After thorough phase separation, the upper layer was collected into glass beakers and the solvent was evaporated at $30{ }^{\circ} \mathrm{C}$ in a Binder BF 53 incubator (Binder, Tuttlingen, Germany).

\section{Phospholipids content}

The phospholipids content was established using the colorimetric method, after Stewart (1980). The extracted fat was weighed out into a polypropylene centrifuge tube and dissolved in $2 \mathrm{~mL}$ of chloroform. Next, $1 \mathrm{~mL}$ of a thiocyanate reagent $(27 \mathrm{~g}$ of ferric chloride and $30 \mathrm{~g}$ of ammonium thiocyanate in $1 \mathrm{~L}$ of distilled water) was added to the tube. The mixture was spun in a Heraeus Megafuge 16 (Thermo Fisher, Waltham, USA) at $1500 \mathrm{rpm}$ for $7 \mathrm{~min}$. After removing the upper red layer, the absorbance of the lower layer was measured at $488 \mathrm{~nm}$ using a Helios Beta spectrophotometer (Spectronic Unicam, United Kingdom). The content of phospholipids in
$1 \mathrm{mg}$ of fat was established based on the curves of absorbance correlation with the phospholipids concentration. Standard solutions of phospholipids (Sigma-Aldrich, Merck, Darmstadt, Germany) were used to plot the standard curve.

\section{Fatty acid profile}

The fat extracts were methylated in accordance with ISO 15884 (2002). The fatty acid profile was determined via gas chromatography using a flame ionization detector (Agilent Technologies, Santa Clara, USA). Experimental conditions were as follows: CP-Sil 88 capillary column $(100 \mathrm{~m}$, $0.25 \mathrm{~mm}, 0.20 \mu \mathrm{m}$ ) (Agilent Technologies $\mathrm{J} \& \mathrm{~W}$ ), temperature gradient: $60{ }^{\circ} \mathrm{C}(1 \mathrm{~min})$ to $180{ }^{\circ} \mathrm{C}$ at $\mathrm{Dt}=5{ }^{\circ} \mathrm{C} /$ min, injector and detector temperatures: 225 and $250{ }^{\circ} \mathrm{C}$ respectively, carrier gas-helium, carrier gas flow rate: $0.8 \mathrm{~mL} \mathrm{~min}^{-1}$, split: 1:100, sample volume: $1 \mu \mathrm{L}$, and liner- $0.4 \mathrm{~mm}$. BCR-164 anhydrous milk fat (LGC Standards, Poland) served as the reference material.

\section{Statistical analysis}

Two experiments were performed. The obtained results were subjected to a 2-way analysis of variance with replications. Differences between all treatment means were compared at the 5\% level of significance using Tuckey's post-hoc test. Results were presented as a mean values \pm standard variation. Data were processed statistically in Microsoft Excel (Microsoft Office 365).

\section{Results and discussion}

The MBMP and MSMP samples for yoghurt production had a dry matter content of $13 \% \pm 0.1 \%$ and milk fat content of $1.5 \% \pm 0.06 \%$.

\section{Rates of acidification}

The rates of acidification did not differ significantly between the milk with buttermilk powder (MBMP) and the milk with skimmed milk powder (MSMP) added for standardization of dry matter content of the milk (Fig. 1). After inoculation with the starter culture (Lactobacillus delbruecki ssp. bulgaricus and Streptococcus thermophilus), the time of acidification was $225 \mathrm{~min}$ and was the same for the two powder additives. In contrast, the changes in $\mathrm{pH}$ during the process indicated that the acidification rate was slightly higher for MSMP than for MBMP. This negligible difference was evident at minute 75 of acidification at $\mathrm{pH}$ 5.3. However, further rates of $\mathrm{pH}$ 


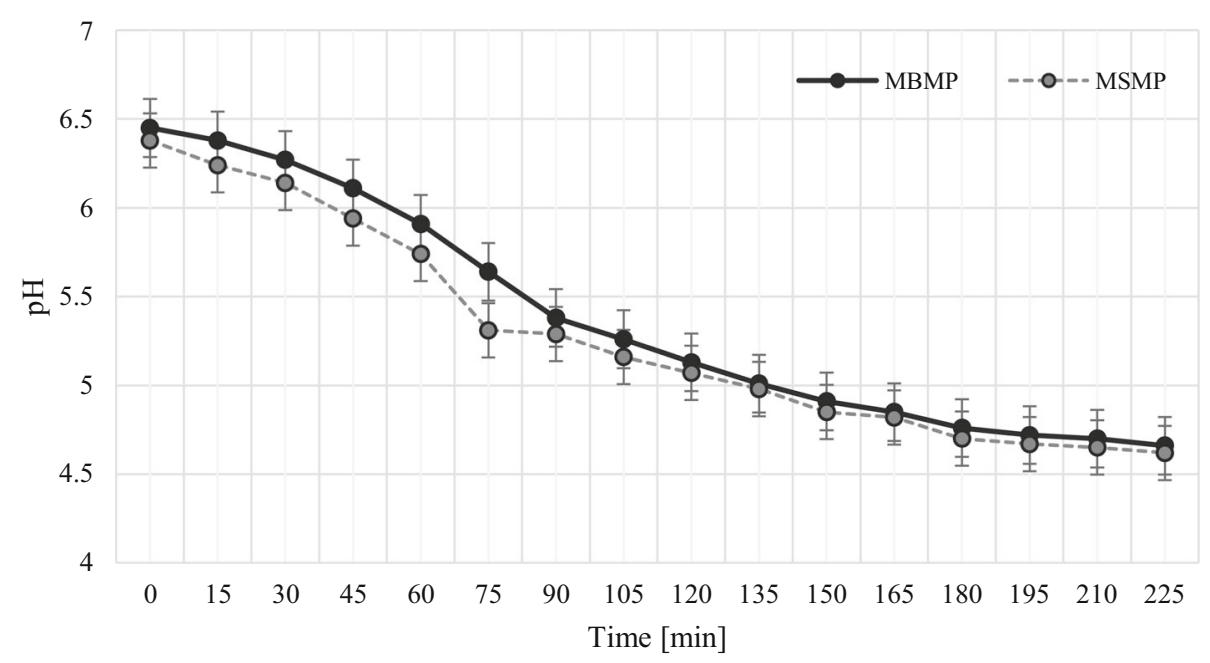

Fig. 1 Acidification curves of milk with added buttermilk powder (MBMP) and milk with added skimmed milk powder (MSMP), mean values \pm standard deviation $(n=2)$

decrease $(<5.3)$ across acidification time were almost identical for both types of milk (Fig. 1).

Romeih et al. (2014) conducted a similar study on the use of buttermilk powder additives in yoghurt production, which differed from the present study due to the use of skimmed buffalo milk. Their study did show that milk supplemented with buttermilk powder was quicker to acidify than the milk supplemented with skimmed milk powder. The authors attributed the faster acidification rates of MBMP to the higher content of peptides or amino acids of lower molecular weight (used by Streptococcus thermophilus) in buttermilk in comparison with skimmed milk. The total time to acidification was recorded at $225 \mathrm{~min}$ (Fig. 1) and did not change between the types of powder used to standardize the milk, which corroborated the results of Le et al. (2011) and Romeih et al. (2014). According to Zhao et al. (2020) addition of buttermilk decreased the $\mathrm{pH}$ at the gelation point, shortened the gelation time and the fermentation period.

During the analysis of the results, 2-way ANOVA showed a statistically significant influence of the type of product, storage time and the interaction on titratable acidity and lactic acid content in the tested samples $(P \leq 0.05$, Table 1$)$. The acidity (expressed in $\mathrm{pH})$, titratable acidity, and lactic acid content of both yoghurts were on similar level after 1 day of storage (Table 1). Prolonged storage led to a decrease in the yoghurt $\mathrm{pH}$, but caused no differences between the yoghurt variants across the analogous chilled storage time $(P>0.05)$. In contrast, differences between the yoghurt variants in terms of titratable acidity and lactic acid content did emerge after 7and 21 -day storage $(P \leq 0.05)$. The titratable acidity and lactic acid content values were higher for YBMP compared with YSMP. The differences in lactic acid content in the analyzed samples were particularly evident after 7 days of storage, though the gap lessened after 21 days of storage (Table 1). Similar studies were conducted by Bonczar and Wszołek (2002), demonstrating a decrease in $\mathrm{pH}$ and an increase in titratable acidity caused by the activity of lactic fermentation bacteria, which continue the conversion of lactose to lactic acid during storage.

The increase in lactic acid content was much slower at the chilled storage temperature (about $4{ }^{\circ} \mathrm{C}$ ) (Table 1) than at the typical ripening temperature for yoghurt starter cultures, as indicated by changes in $\mathrm{pH}$ values (Fig. 1).

\section{Yoghurt syneresis}

Figure 2 shows the effect of the type of powder used in the yoghurt production mixture on the syneresis of the final product throughout storage.

A change of approximately 5\% was detected for YSMP (increase) and YBMP (decrease) syneresis during storage. Yoghurt syneresis often occurs during storage and constitutes a serious defect. As such, reducing whey separation represents an improvement for the consumer. The results are corroborated by studies of Le et al. (2011), Romeih et al. (2014), Trachoo and Mistry (1998) and Zhao et al. (2020) who demonstrated lower values of syneresis for the yoghurt with buttermilk, as buttermilk constituents provide better water holding capacity.

Given that the dry matter content of both yoghurts was the same, the reduced (not significantly) syneresis of YBMP compared with YSMP (Fig. 2) was explained by 
Table $1 \mathrm{pH}$, titratable acidity and lactic acid content of yoghurt during storage

\begin{tabular}{|c|c|c|c|c|c|c|c|}
\hline \multirow[t]{2}{*}{ Days of storage at $4{ }^{\circ} \mathrm{C}$} & & \multicolumn{2}{|l|}{$\mathrm{pH}$} & \multicolumn{2}{|c|}{ Titratable acidity $\left[{ }^{\circ} \mathrm{SH}\right]$} & \multicolumn{2}{|l|}{ Lactic acid [\%] } \\
\hline & & YBMP & YSMP & YBMP & YSMP & YBMP & YSMP \\
\hline 1 & & $4.45 \pm 0.01^{\mathrm{a}}$ & $4.46 \pm 0.03^{\mathrm{a}}$ & $45.1 \pm 0.1^{\mathrm{a}}$ & $45.0 \pm 0.3^{\mathrm{a}}$ & $1.015 \pm 0.002^{\mathrm{a}}$ & $1.013 \pm 0.002^{\mathrm{a}}$ \\
\hline 7 & & $4.37 \pm 0.01^{\mathrm{b}}$ & $4.37 \pm 0.01^{\mathrm{b}}$ & $51.4 \pm 0.6^{\mathrm{b}}$ & $47.6 \pm 0.6^{\mathrm{b}}$ & $1.157 \pm 0.009^{b}$ & $1.071 \pm 0.009^{\mathrm{b}}$ \\
\hline 21 & & $4.26 \pm 0.01^{\mathrm{c}}$ & $4.27 \pm 0.01^{\mathrm{c}}$ & $52.4 \pm 0.6^{\mathrm{c}}$ & $51.3 \pm 0.1^{\mathrm{c}}$ & $1.179 \pm 0.009^{\mathrm{c}}$ & $1.154 \pm 0.002^{\mathrm{c}}$ \\
\hline \multirow[t]{3}{*}{ Significance ( $P$ value) } & Product & not significant & & 0.000 & & 0.000 & \\
\hline & Storage & 0.000 & & 0.000 & & 0.000 & \\
\hline & Interaction & not significant & & 0.002 & & 0.002 & \\
\hline
\end{tabular}

Values are means \pm standard deviation $(n=2)$; YBMP—yoghurt with added buttermilk powder; YSMP—yoghurt with added skimmed milk powder

Mean values in columns (for the same product) with different superscripts are significantly different $(P \leq 0.05)$; experimental factor: days of storage

60

口YBMP $\quad$ YYSMP

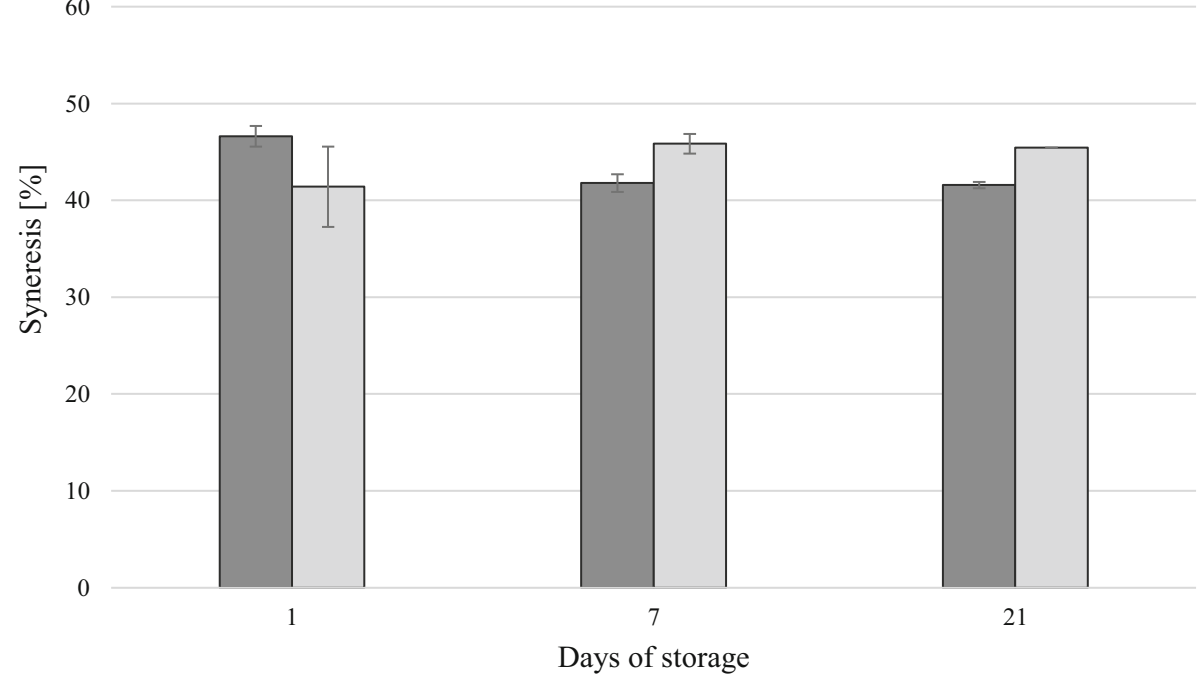

Fig. 2 Syneresis of yoghurt during storage. YBMP-yoghurt with added buttermilk powder; YSMP-yoghurt with added skimmed milk powder. Mean values \pm standard deviation $(n=2)$, differences not significant

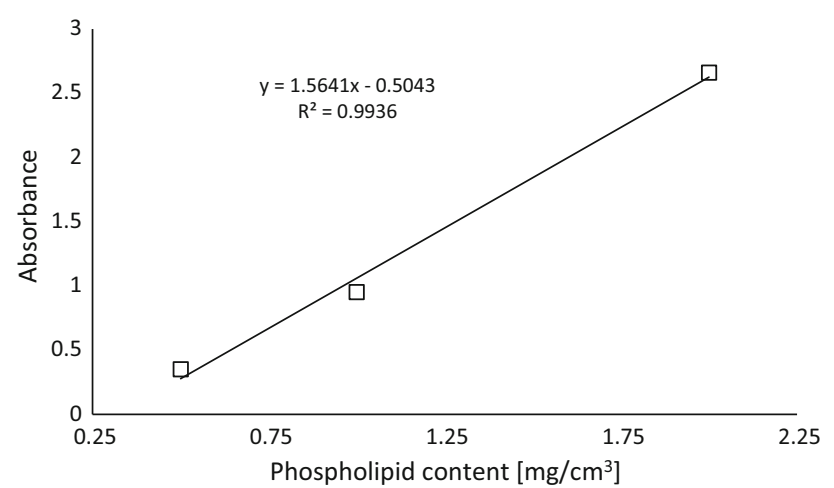

Fig. 3 Absorbance of the standard phospholipid solution the increased hydration capacity of its constituents, in particular MFGM proteins and phospholipids. The amphiphilic properties of phospholipids and other constituents of milk fat globule membranes may translate into a higher capacity for water retention.

\section{Phospholipids in yoghurt}

The standard curve was plotted based on standard solutions with defined phospholipids concentrations (Fig. 3). The high coefficient of determination for the linear relationship between absorbance and phospholipids concentration points to the validity of the employed method.

During the analysis of the results, 2-way ANOVA showed a statistically significant influence of the type of 
product and storage time on phospholipid content in the tested samples $(P \leq 0.05$, Table 2$)$. The present study demonstrated lower $(P \leq 0.05)$ phospholipids contents in the milk fat from the yoghurt supplemented with buttermilk powder, as compared with the yoghurt with skimmed milk powder. The proportion of phospholipids in milk fat in the fermented products decreased during storage $(P \leq 0.05)$. The variation in phospholipids content between the two types of powder was particularly evident in yoghurt after 21 days of storage. Throughout the 21-day storage, the phospholipids content decreased faster in YBMP, maximally by ca. $50 \%$, whereas the decrease in YSMP amounted to about $20 \%$ compared to the similar samples stored for 1 day. After storage, the phospholipids content in YSMP was 50\% higher than in YBMP $(P \leq 0.05)$.

The high phospholipids content in YBMP results from the fat globule membranes being released into the buttermilk during the churning process, whereas in the case of YSMP, it is caused by the high content of very small fat globules, as well as the extensive interface surface of the skimmed milk. In both cases, the addition of the powder products resulted in a high proportion of phospholipids in milk fat (Table 2).

The presence of small fat globules results in a higher content of polar lipids in the product compared to the large fat globules (Lopez 2011). Conway et al. (2014), Mac Gibbon (2006), and Rombaut and Dewettinck (2006) reported that the content of polar lipids was high in both buttermilk and skimmed milk relative to total fat. Although the phospholipids content of buttermilk is 10 times higher than that of skimmed milk, the proportion of phospholipids

Table 2 Phospholipid content in yoghurt

\begin{tabular}{lll}
\hline Days of storage at $4^{\circ} \mathrm{C}$ & Type of yoghurt & $\begin{array}{l}\text { Phospholipid content } \\
{[\mathrm{mg} / \mathrm{g} \text { of fat }]}\end{array}$ \\
\hline 1 & YBMP & $99.6 \pm 2.9^{\mathrm{a}}$ \\
& YSMP & $127.4 \pm 0.4^{\mathrm{a}}$ \\
7 & YBMP & $98.0 \pm 4.2^{\mathrm{a}}$ \\
& YSMP & $118.8 \pm 2.5^{\mathrm{a}}$ \\
21 & YBMP & $67.6 \pm 2.6^{\mathrm{b}}$ \\
& YSMP & $104.8 \pm 7.9^{\mathrm{b}}$ \\
Significance $(P$ value $)$ & Product & 0.000 \\
& Storage & 0.000 \\
& Interaction & not significant
\end{tabular}

Values are means \pm standard deviation $(n=2)$; YBMP-yoghurt with added buttermilk powder; YSMP_-yoghurt with added skimmed milk powder

Mean values in columns (for the same product) with different superscripts are significantly different $(P \leq 0.05)$; experimental factor: days of storage to total fat is similar in both products (Conway et al. 2014; Mac Gibbon 2006).

The fact that the phospholipids content changes less radically in YSMP compared to YBMP during storage can most likely be explained by the phospholipids from buttermilk-powder MFGM fragments being more susceptible to conversion than the phospholipids present on the surface of fat globules in skimmed milk powder. Further research is, however, needed to explain why those specific changes in the phospholipids content occur in the dry matter of yoghurt fortified with buttermilk powder.

\section{Fatty acid profile}

The fatty acid profile of yoghurts did not vary depending on the composition of the production mixture (Table 3).

The literature data (Fauquant et al. 2005; Jhanwar and Ward 2014; Sanchez-Juanes et al. 2009) indicates that the composition of fatty acids can differ depending on their source of origin. The fatty acid profile of phospholipids from buttermilk fat globule membranes differs from that of fat extracted from whole milk. Such phospholipids not only have lower levels of stearic acid and higher levels of oleic and linoleic acids, but also contain very long chain fatty acids (VLCFA), larger than C20 (Sanchez-Juanes et al. 2009), and more unsaturated fatty acids-in particular PUFAs (Polyunsaturated Fatty Acids), whose levels are 6 times higher on the membrane than in the inner core of the globule (Fauquant et al. 2005; Jhanwar and Ward 2014).

Table 3 Fatty acid profile of yoghurt

\begin{tabular}{lll}
\hline Fatty acid g $100 \mathrm{~g}^{-1}$ total fatty acids & YBMP & YSMP \\
\hline C $4: 0$ & $2.82 \pm 0.06$ & $2.75 \pm 0.09$ \\
C $6: 0$ & $1.96 \pm 0.10$ & $1.92 \pm 0.05$ \\
C $8: 0$ & $1.25 \pm 0.02$ & $1.23 \pm 0.05$ \\
C $10: 0$ & $3.03 \pm 0.06$ & $2.99 \pm 0.07$ \\
C $12: 0$ & $3.73 \pm 0.18$ & $3.69 \pm 0.12$ \\
C $14: 0$ & $12.89 \pm 0.27$ & $12.79 \pm 0.18$ \\
C $14: 1$ & $1.06 \pm 0.02$ & $1.09 \pm 0.09$ \\
C $15: 0$ & $1.13 \pm 0.09$ & $1.16 \pm 0.08$ \\
C $16: 0$ & $36.48 \pm 0.28$ & $36.45 \pm 0.42$ \\
C $16: 1$ & $1.84 \pm 0.09$ & $1.89 \pm 0.06$ \\
C $18: 0$ & $11.02 \pm 0.18$ & $11.02 \pm 0.16$ \\
C $18: 1 \mathrm{t} 9$ & $1.43 \pm 0.13$ & $1.39 \pm 0.10$ \\
C18:1 c9 & $20.20 \pm 0.93$ & $20.42 \pm 0.89$ \\
C18:2 c6 & $1.17 \pm 0.07$ & $1.22 \pm 0.08$ \\
\hline
\end{tabular}

Values are means \pm standard deviation $(n=2)$; YBMP-yoghurt with added buttermilk powder; YSMP_-yoghurt with added skimmed milk powder. Differences not significant 
In the present study, the use of buttermilk powder in yoghurt production caused no changes in the respective fatty acid profile (Table 3 ). This is most likely due to the milk fat content being higher relative to the membrane lipids, as well as to the similar phospholipids content in yoghurts with added buttermilk powder and yoghurts with added skimmed milk powder (Table 2).

\section{Conclusion}

The boosted wholesomeness of food is mostly determined by the presence of bioactive substances. In this regard, naturally fermented milk beverages produced using sweet buttermilk can be considered beneficial to human health. The yoghurts with added buttermilk contained less phospholipids when compared with the yoghurts supplemented with milk powder. No differences were found in fatty acid profiles of the two yoghurts with different powders used as additives. The use of buttermilk powder in yoghurt production did not disrupt the milk fermentation process. It did, however, contribute to the increased lactic acid content and a higher water-holding capacity of the stored yoghurt. The reduction in yoghurt syneresis after buttermilk powder addition can be considered as an improvement in product quality, particularly from the consumers' perspective. Thus, we can conclude that buttermilk can be used as an additive to produce a novel yoghurt type with functional features.

Acknowledgements The authors would like to thank Justyna Ziajka for technical assistance during the study.

\begin{abstract}
Author contributions All authors have contributed equally to this manuscript. Anna Garczewska-Murzyn-performing analyses, writing a manuscript, revision of manuscript. Michał Smoczyński concept of research, writing a manuscript, management of research. Natalia Kotowska-performing analyses, data analysis. Katarzyna Kiełczewska - data analysis, writing a manuscript, proof reading of manuscript.
\end{abstract}

Funding This research did not receive any specific Grant from funding agencies in the public, commercial, or not-for-profit sectors.

Availability of data and material All data generated or analyzed during this study are included in this published article.

\section{Declarations}

Conflict of interest Authors declare that the work has not been published before and it is not under consideration for publication elsewhere.

Ethics approval This author declare that there is no conflict of interest.

Consent to participate Submission to Journal of Food Science and Technology publication has been approved by all authors as well as the responsible authorities at the institute where the work has been carried out.

Open Access This article is licensed under a Creative Commons Attribution 4.0 International License, which permits use, sharing, adaptation, distribution and reproduction in any medium or format, as long as you give appropriate credit to the original author(s) and the source, provide a link to the Creative Commons licence, and indicate if changes were made. The images or other third party material in this article are included in the article's Creative Commons licence, unless indicated otherwise in a credit line to the material. If material is not included in the article's Creative Commons licence and your intended use is not permitted by statutory regulation or exceeds the permitted use, you will need to obtain permission directly from the copyright holder. To view a copy of this licence, visit http://creativecommons. org/licenses/by/4.0/.

\section{References}

Amatayakul T, Sherkat F, Shah NP (2006) Syneresis of set yoghurt as affected by EPS starter cultures and levels of solids. Int J Dairy Technol 59:216-221. https://doi.org/10.1111/j.1471-0307.2006. 00264.x

Anto L, Warykas SW, Torres-Gonzalez M, Blesso ChN (2020) Milk polar lipids: underappreciated lipids with emerging health benefits. Review Nutrients. https://doi.org/10.3390/nu12041001

Bonczar G, Wszołek M (2002) Charakterystyka jogurtów z mleka owczego o normalizowanej zawartości tłuszczu. ZYWN-NAUK TECHNOL JA 1(30):111-112

Contarini G, Povolo M (2013) Phospholipids in milk fat: composition, biological and technological significance, and analytical strategies. Int J Mol Sci 14:2808-2831. https://doi.org/10.3390/ ijms 14022808

Conway V, Gauthier SF, Pouliot Y (2014) Buttermilk: Much more than a source of milk phospholipids. Anim Front 4(2):44-51. https://doi.org/10.2527/af.2014-0014

Corredig M, Dalgleish DG (1997) Isolates from industrial buttermilk: emulsifying properties of materials derived from the milk fat globule membrane. J Agric Food Chem 45:4595-4600. https:// doi.org/10.1021/jf970531f

Dewettinck K, Rombaut R, Thienpont N, Le TT, Messens K, Van Camp J (2008) Nutritional and technological aspects of milk fat globule membrane material. Int Dairy J 18:436-457. https://doi. org/10.1016/j.idairyj.2007.10.014

Fauquant C, Briard V, Leconte N, Michalski C (2005) Differently sized native milk fat globules separated by microfilftration: fatty acid composition of the milk fat globule membrane and triglyceride core. Eur J Lipid Sci Technol 107:80-86. https:// doi.org/10.1002/ejlt.200401063

Fontecha J, Brink L, Wu S, Pouliot Y, Visioli F, Jiménez-Flores R (2020) Sources, production, and clinical treatments of milk fat globule membrane for infant nutrition and well-being. Nutrients 12:1607. https://doi.org/10.3390/nu12061607

Hara A, Radin NS (1978) Lipid extraction of tissues with low-toxicity solvent. Anal Biochem 90:420-425. https://doi.org/10.1016/ 0003-2697(78)90046-5

Horiuchi H, Sasaki Y (2012) Effect of oxygen on symbiosis between Lactobacillus bulgaricus and Streptococcus thermophilus. J Dairy Sci 95:2904-2909. https://doi.org/10.3168/jds.20115147

ISO 15884:2002. IDF 182:2002. Milk fat - Preparation of fatty acid methyl esters

ISO 19662:2018. IDF 238. Milk - Determination of fat content Acido-butyrometric (Gerber method) 
Jhanwar A, Ward RE (2014) Particle size distribution and lipid composition of skim milk lipid material. Int Dairy J 36:110-117. https://doi.org/10.1016/j.idairyj.2014.01.010

Jørgensen CE, Abrahamsen RK, Rukke E-O, Hoffmann TK, Johansen A-G, Skeie SB (2019) Processing of high-protein yoghurt - A review. Int Dairy J 88:42-59. https://doi.org/10.1016/j.idairyj. 2018.08.002

Korhenen H (2009) Bioactive components in bovine milk. In: Park YW (ed) Bioactive Components in Milk and Dairy Products. Wiley-Blackwell, Singapure, pp 15-42

Le TT, van Camp J, Pascual PAL, Meesen G, Thienpont N, Messens K, Dewettinck K (2011) Physical properties and microstructure of yoghurt enriched with milk fat globule membrane material. Int Dairy J 21:798-805. https://doi.org/10.1016/j.idairyj.2011. 04.015

Lopez C (2011) Milk fat globules enveloped by their biological membrane: Unique colloidal assemblies with a specific composition and structure. Curr Opin Colloid Interface Sci 16:391-404. https://doi.org/10.1016/j.cocis.2011.05.007

MacGibbon AKH, Taylor MW (2006) Composition and structure of bovine milk lipids. In: Fox PF, McSweeney PLH (eds) Advanced Dairy Chemistry, vol 2. Lipids. Springer, New York, pp 1-43

Rombaut R, Dewettinck K (2006) Properties, analysis and purification of milk polar lipids. Int Dairy J 16:1362-1373. https://doi.org/10. 1016/j.idairyj.2006.06.011

Romeih EA, Abdel-Hamid M, Awad AA (2014) The addition of buttermilk powder and transglutaminase improves textural and organoleptic properties of fat-free buffalo yogurt. Dairy Sci Technol 94:302-303. https://doi.org/10.1007/s13594-014-01638

Sanchez-Juanes F, Alonso JM, Zancada L, Hueso P (2009) Distribution and fatty acid content of phospholipids from bovine milk and bovine milk fat globule membranes. Int Dairy J 19:273-278. https://doi.org/10.1016/j.idairyj.2008.11.006
Silva JVC, O’Mahony JA (2017) Flowability and wetting behaviour of milk protein ingredients as influenced by powder composition, particle size and microstructure. Int $\mathbf{J}$ Dairy Technol 70(2):277-286. https://doi.org/10.1111/1471-0307.12368

Smoczyński M, Staniewski B, Kiełczewska K (2012) Composition and structure of the bovine milk fat globule membrane - some nutritional and technological implications. Food Rev Int 28(2):188-202. https://doi.org/10.1080/87559129.2011.595024

Spitsberg VL (2005) Bovine milk fat globule membrane as a potential nutraceutical. J Dairy Sci 88(7):2289-2294. https://doi.org/10. 3168/jds.S0022-0302(05)72906-4

Stewart JCM (1980) Colorimetric determination of phospholipids with ammonium ferrothiocyanate. Anal Biochem 104:10-14. https://doi.org/10.1016/0003-2697(80)90269-9

Trachoo N, Mistry VV (1998) Application of ultrafiltered sweet buttermilk and sweet buttermilk powder in the manufacture of nonfat and low fat yogurts. J Dairy Sci 81:3163-3171. https:// doi.org/10.3168/jds.S0022-0302(98)75882-5

Vanderghem C, Bodson P, Danthine S, Paquot M, Deroanne C, Blecker Ch (2010) Milk fat globule membrane and buttermilks: from composition to valorization. Biotechnol Agron Soc Environ 14(3):485-500

Zhao L, Feng R, Rena F, Mao X (2018) Addition of buttermilk improves the flavor and volatile compound profiles of low-fat yogurt. LWT 98:9-17. https://doi.org/10.1016/j.lwt.2018.08.029

Zhao L, Feng R, Mao X (2020) Addition of buttermilk powder improved the rheological and storage properties of low-fat yogurt. Food Sci Nutr 8(7):3061-3069. https://doi.org/10.1002/ fsn3.1373

Publisher's Note Springer Nature remains neutral with regard to jurisdictional claims in published maps and institutional affiliations. 